Ksenija Šulović*

UDK 811.133.1'37:811.163.41'37

Dragana Drobnjak

$811.134 .2 ' 373.7: 811.163 .41 ' 373.7$

Snežana Gudurić

$811.163 .41 ' 373.7$

Filozofski fakultet

DOI: $10.19090 / g f f .2018 .1 .337-356$

Univerzitet u Novom Sadu

\title{
FRAZEMI SA SOMATIZMOM GLAVA U FRANCUSKOM, ŠPANSKOM I SRPSKOM JEZIKU***
}

Konceptualno polje 'čovekove osobine'

U radu se razmatraju francuski, španski i srpski frazemi sa somatizmom fr. tête / šp. cabeza / srp. glava koji kvalifikuju čovekove fizičke, karakterne, umne i moralne osobine. Cilj rada je da metodom kontrastivne leksičko-semantičke analize ustanovimo (ne)podudarnost leksičke i semantičke strukture posmatranih frazema u trima jezicima, odnosno (ne)podudaranje koncepata koje oni izražavaju. Korpus, ekscerpiran iz francuskih, španskih i srpskih opštih i frazeoloških rečnika, dnevnih i nedeljnih novina i elektronskih izvora, čini 174 frazema koji pripadaju standardnom jeziku.

Ključne reči: lingvokulturologija, frazem, glava, konceptualno polje 'čovekove osobine', francuski, španski, srpski.

\section{UVOD}

Somatizmi predstavljaju veoma bitno i drevno semantičko polje, te stoga čine jednu od frazeoloških i jezičkih univerzalija (Ĉermák, 2000: 57). Oni se odlikuju izuzetnim tvorbenim, semantičkim i frazemotvornim potencijalom (Matijašević, 2003) i visokom frekventnošću (Kovačević, 2012). Budući da prevashodno upućuju na čoveka (njegove osobine, stanja, ponašanje, odnos sa okruženjem), somatski frazemi ${ }^{1}$ su izrazito antropocentrični i antropometrični i izviru iz univerzalno prisutnih metafora motivisanih čovekovim telesnim

\footnotetext{
*ksenijasulovic@ff.uns.ac.rs

** Rad je urađen u okviru projekta Jezici i kulture u vremenu i prostoru (broj 178002) koji finansira Ministarstvo prosvete, nauke i tehnološkog razvoja Republike Srbije.

${ }^{1}$ Pod frazemom podrazumevamo osnovnu jedinicu frazeologije, koja se sastoji od najmanje dve komponente i koju karakterišu čvrsta struktura, ustaljenost, reproduktivnost i idiomatičnost (Burger, 2003).
} 
iskustvom. Oni predstavljaju kompleksan i dragocen materijal, koji se često i svrsishodno upotrebljava u savremenom jeziku.

Budući da su dosadašnja proučavanja somatskih frazema vršena u okviru jednog ili dvaju jezika, u nameri da obogatimo višejezička lingvokulturološka istraživanja, u ovom radu uporedićemo francuske, španske i srpske somatske frazeme, i to one sa komponentom glava. ${ }^{2}$ Budući da su frazemi sa ovim somatizmom izuzetno brojni i da ih prema semantičkom talogu možemo razvrstati u više konceptualnih polja ('čovekove osobine', 'čovekova stanja', 'čovekovo ponašanje i odnos prema okruženju', 'apstraktni pojmovi', 'okolnosti'), u ovom radu predstavićemo samo konceptualno polje 'čovekove osobine'. Cilj našeg rada jeste da metodom kontrastivne leksičko-semantičke analize ustanovimo (ne)podudarnost leksičke i semantičke strukture posmatranih frazema u trima jezicima, odnosno način na koji govornici triju lingvokulturoloških zajednica konceptualizuju sadržaje izražene putem ovih somatskih frazema.

Korpus za ovo istraživanje, koji čini 174 frazema (63 francuska, 52 španska i 59 srpskih), ekscerpirale smo iz francuskih, španskih i srpskih opštih i frazeoloških rečnika, dnevnih i nedeljnih novina, kao i iz elektronskih izvora. Odabrani frazemi pripadaju standardnom francuskom, španskom i srpskom jeziku i potvrđeni su u savremenoj jezičkoj praksi.

Korpus sadrži frazeme u kojima se somatizam fr. tête / šp. cabeza / srp. glava javlja bilo kao primarna ${ }^{3}$ (npr. fr. avoir une tête de fer; avoir la tête chaude; šp. ser cabeza caliente; ser cabeza torcida; srp. imati glavu kao tele; imati hladnu glavu), bilo kao sekundarna komponenta (npr. fr. la gloire, le pouvoir monte à la tête de quelqu'un; šp. tener pájaros en la cabeza; tener agua en la cabeza; srp. zavadio bi dva oka u glavi; imati klikere u glavi). Frazemske varijante koje ne ugrožavaju stabilnost frazeološke strukture, njeno monolitno značenje i reproduktivnost (npr. šp. ser cabeza dura, tener la cabeza dura; srp. faliti kome jedna/treća daska u glavi) u našoj analizi posmatrane su kao istovetne.

U korpus smo uvrstile frazeme koji pripadaju frazeologiji u užem smislu, te su iz njega izuzete poslovice (npr. Más vale la cabeza de ratón que cola de león; Pametna glava - stotinu ruku; S glave riba smrdi), kletve (npr. glave se ne nanosio;

\footnotetext{
${ }^{2}$ O somatizmu glava videti i: Cortès, 1998-1999; Olza Moreno, 2006; Razdobudko-Čović, 2003; Dragićević, 2009; Andrić, 2013; Ristić, 2013; Trivić, 2015; Štrbac-Štasni, 2017.

3 Odrednice primarna i sekundarna komponenta ukazuju isključivo na redosled komponenata u frazemu, a ne na njihovu vrednost (Kovačević, 2012).
} 
bestraga ти glava), kolokacije sa gestovima u pozadini koje nisu prošle kroz proces frazeologizacije i psovke.

\section{KONCEPTUALNO POLJE 'ČOVEKOVE OSOBINE'}

2.1. Glava se smatra najznačajnijim delom čovekovog tela, budući da se u njoj nalazi mozak, koji upravlja celokupnim radom organizma i koji je izvorište misaonih procesa, sedište uma, intelekta, memorije i imaginacije.

Imenice fr. tête / šp. cabeza / srp. glava ulaze u osnovni leksički fond triju posmatranih jezika i izrazito su višeznačne. Uprkos različitoj leksikografskoj obradi u relevantnim francuskim, španskim i srpskim rečnicima (TLF, DRAE, RSJ, RSANU), uočavamo da se osnovna značenja podudaraju u trima jezicima: a) 'gornji deo čovečijeg, odnosno prednji deo životinjskog tela, u kome su smešteni mozak, glavna čula i prednji deo probavnog i disajnog sistema' i b) 'pamet, inteligencija, um, razum; svest, misli'. Pojedina figurativna i sekundarna značenja podudaraju se u trima jezicima, dok su neka specifična za svaki od njih ponaosob. ${ }^{4} \mathrm{Za}$ naš rad relevantne su dve navedene semantičke realizacije koje indukuju nastanak somatskih frazema. Našim istraživanjem analiziraćemo (ne)istovetnost konceptualizacije ovih sadržaja u konceptualnom polju 'čovekove osobine'.

2.2. U kognitivnoj lingvistici frazemi predstavljaju psiholingvističke jedinice unutar 'mentalnog leksikona', koji je istkan od mreže pojmovnih jedinica razvrstanih u jedno ili više konceptualnih polja. Međe ovih polja uslovili su izvanjezički kriterijumi i one su utemeljene na celokupnom čovekovom znanju o svetu. Metoda semantičke dekompozicije izvorište je konceptualno-semantičkog umreženja frazema, te se frazemima pridružuju odgovarajući deskriptori, zapravo, njihova relevantna obeležja zasnovana na sličnosti. Dobrovoljski (prema: Zybatow, 1997: 582) predlaže 'tehniku grozdova', prema kojoj frazeme istog grozda povezuje semantička sličnost na intuitivnom nivou. Kontekst je često presudan za pridruživanje deskriptora frazemima, te pojedine višeznačenjske frazeme može da karakteriše više deskriptora. S druge strane, frazemi unutar jednog grozda, združeni u značenjsku celinu zahvaljujući istom relevantnom obeležju, ne moraju obavezno da dele isti deskriptor.

Sledeći ovakvu metodologiju, konceptualno polje 'čovekove osobine' podelile smo na četiri podgrupe, na osnovu toga da li je reč o fizičkim (2.2.1), karakternim (2.2.2), umnim (2.2.3) ili moralnim odlikama (2.2.4).

\footnotetext{
${ }^{4}$ Videti detaljnije odrednice: tête u TLF, cabeza u DRAE, glava u RSANU.
} 
U našem istraživanju pod leksičkim poklapanjem podrazumevamo prisustvo istih ili sličnih komponenata u frazemima triju jezika, a pod semantičkim istovetan koncept koji oni izražavaju. Frazeme istog ili sličnog značenja, ali neistovetne leksičke strukture smatramo delimičnim ekvivalentima, te ih stoga posebno navodimo. Kod francuskih i španskih primera za koje ne pronalazimo ekvivalent u srpskom jeziku u zagradi dajemo doslovno (često agramatično) značenje komponenata frazema, a ne frazeološko značenje. Doslovno značenje frazeoloških komponenata veoma je važan kriterijum, budući da odnos doslovnog i frazeološkog značenja ukazuje na (ne)prozirnost motivacije i određuje stepen idiomatičnosti.

Pojedini frazemi realizuju više značenja. Ukoliko neka značenja premašuju okvire konceptualnog polja 'čovekove osobine', u radu ih pominjemo u fusnoti, bez podrobnije analize.

U radu smo, tamo gde smo to smatrale neophodnim za jasniju klasifikaciju frazema, navodile pojmovne metafore i metonimije, ne ulazeći dublje u njihova tumačenja, budući da one nisu prevashodni predmet ovog rada.

2.2.1. FIZIČKE ODLIKE. U ovu skupinu uvrstile smo frazeme koji odslikavaju izgled čovekove glave. U njima se ona poredi sa veličinom i oblikom glave pojedinih životinja. Time se veoma ekspresivno izražavaju omalovažavanje i vređanje nečijeg fizičkog izgleda. ${ }^{5}$ Zanimljivo je da se u francuskoj i srpskoj lingvokulturološkoj zajednici koriste različiti etaloni: u francuskom su to koza, ptica, papagaj, pacov, dakle prevashodno male životinje, a u srpskom svinja, bik i tele, koje karakteriše velika glava. Samo u jednom primeru, i to u španskom i srpskom, uočavamo zajednički etalon (konj):

\section{fr. - / šp. tener cabeza como caballo / srp. imati glavu kao konj;}

\footnotetext{
${ }^{5}$ Za konceptualizaciju raznolikih pojmova važan je kulturni model ,veliki lanac postojanja” (Kövecses, 2002), proistekao iz težnje da se objasni poredak u kosmosu. Zasnovan je na čvrsto definisanoj hijerarhiji svega postojećeg i predstavlja vertikalnu skalu bića (ljudi, životinja, biljaka) i predmeta. Na ovoj se skali „viša” bića i svojstva nalaze iznad „nižih bića i svojstava” (Lakoff-Turner, 1989: 166). „Tako su ljudi bića „višeg” nivoa budući da ih krase razum, svest, moralnost, volja, osećaj za estetiku i druge osobine nesvojstvene životinjama koje odlikuju isključivo instinktivni i uslovljeni oblici ponašanja, te su one bića „nižeg” nivoa u odnosu na čoveka. [...] Metafora zasnovana na velikom lancu postojanja nastaje kada se jedan njegov nivo (npr. čovek) preslika na neki drugi nivo (npr. životinje). Pomoću ovakvog kulturnog modela opšte ljudske osobine razumeju se na osnovu dobro poznatih neljudskih svojstava" (Drobnjak-Šulović, 2016: 9).
} 
fr. avoir une tête de chèvre (*imati glavu koze) / šp. - / srp. -;

fr. avoir une tête d'oiseau (*imati glavu ptice) / šp. - / srp. -;

fr. avoir une tête de perroquet (*imati glavu papagaja) / šp. - / srp. -;

fr. avoir une tête de rat (*imati glavu pacova) / šp. - / srp. -;

fr. - / šp. - / srp. imati glavu kao svinja;

fr. - / šp. - / srp. imati glavu kao bik;

fr. - / šp. - / srp. imati glavu kao tele.

Prema istovetnoj frazeoshemi, čovekova glava poredi se i sa kakvim predmetom ili voćem okruglog ili duguljastog oblika, pri čemu francuska i srpska lingvokulturološka zajednica koriste isti etalon - bundevu:

fr. avoir la tête [grosse] comme une citrouille ${ }^{6} /$ šp. - / srp. imati glavu [veliku] kao bundeva;

fr. avoir la tête [grosse] comme une pastèque (*imati glavu [veliku] kao lubenica) / šp. - / srp. -;

fr. - / šp. tener cabeza de tarro $^{7}$ (*imati glavu ćupa) / srp. - .

U francuskom i španskom jeziku ćelavost se poredi sa oguljenim povrćem, voćem ili kožom: fr. avoir une tête pelée (*imati glavu oljuštenu) / šp. tener la cabeza pelada (*imati glavu oljuštenu).

U pojedinim francuskim frazemima uočljiv je metonimijski odnos CELINA ZA DEO, budući da glava zapravo upućuje na lice, bilo u pozitivnom, bilo u negativnom kontekstu. Takve frazeme ne pronalazimo u španskom i srpskom jeziku, koji u ovakvim slučajevima koriste lekseme šp. cara / srp. lice:

- 'imati prijatno lice koje uliva poverenje i simpatiju':

fr. avoir une bonne tête ${ }^{8}$ (*imati dobru glavu) / šp. - / srp. -;

- 'imati odbojno lice':

fr. avoir une sale tête ${ }^{9}$ (*imati prljavu glavu) / šp. - / srp. -;

\footnotetext{
${ }^{6}$ Vidi i: Marjanović, 2017.

${ }^{7}$ Frazem je polisemičan, te je sa odgovarajućim deskriptorom svrstan i među umne odlike.

${ }^{8}$ I ovaj frazem je polisemičan, te ga navodimo i među umnim odlikama.

9 Frazem je višeznačan, ali njegova značenja 'biti umoran' i 'biti lošeg zdravlja' nisu predmet ovog rada.
} 
fr. il a une tête qui ne nous revient pas (*ima glavu koja nam se ne vraća) / šp. - / srp. -;

fr. avoir une tête à claques, à gifles (*imati glavu za šamare) / šp. - / srp. - .

$\mathrm{U}$ francuskom jeziku pronalazimo frazeme avoir une tête de + imenica $\mathrm{i}$ avoir une tête à + imenica, koji upućuju na stereotipnog predstavnika kakve pozitivno ili negativno konotirane aktivnosti ili osobine (npr. avoir une tête d'ange, d'assassin, d'imbécile, d'ivrogne (*imati glavu anđela, ubice, imbecila, pijanca), avoir une tête à l'emploi, à tromper les gens (*imati glavu za posao, za varanje ljudi)). U navedenim frazemima takođe se uočava metonimijski odnos CELINA ZA DEO, odnosno GLAVA ZA LICE. I u ovakvim slučajevima španskom i srpskom jeziku bila bi svojstvena upotreba leksema šp. cara i srp. lice.

Samo u srpskom jeziku pronalazimo jedan frazem koji označava sličnost sa drugom osobom: biti nečija odsečena glava.

2.2.2. KARAKTERNE ODLIKE. Nešto su brojniji frazemi kojima se iskazuje kakva karakterna odlika i oni su mahom negativno obojeni. Zanimljivo je da smo u ovoj grupi pronašle samo dva primera leksičko-semantičkog poklapanja u trima jezicima, i to jedan sa negativnom i jedan sa pozitivnom konotacijom. Poklapanja u dvama jezicima tek su sporadična.

Čovekova tvrdoglavost i nepopustljivost porede se sa kakvom tvrdom materijom, alatkom ili životinjom, prevashodno mazgom. Ovakvi frazemi najbrojniji su u francuskom jeziku, dok u srpskom ne pronalazimo niti jedan:

fr. avoir une tête de fer (*imati glavu od gvožđa) / šp. tener cabeza de hierro ${ }^{10}$ (*imati glavu od gvožđa) / srp. -;

fr. avoir une tête de bois (*imati glavu od drveta) / šp. - / srp. -;

fr. avoir une tête de pioche (*imati glavu pijuka) / šp. - / srp. -;

fr. avoir une tête de mule (*imati glavu mazge) / šp. - / srp. $-{ }^{11}$

\footnotetext{
10 Drugo značenje polisemičnog španskog frazema ('osoba koja ne oseća umor uprkos mentalnom naporu') nije predmet ovog rada.

${ }^{11} \mathrm{U}$ srpskom jeziku postoji korespondentni frazem biti tvrdoGLAV kao mazga, ali on nije uvršten u naš korpus, budući da ne sadrži somatizam glava.
} 
U narednim frazemima svojeglavost ističu pridevi kojima se kvalifikuje glava, pri čemu sva tri jezika upotrebljavaju pridev $t v r d$, a dva romanska i pridev koji upućuje na oblik - četvrtast:

fr. avoir la tête dure / šp. ser cabeza dura, tener la cabeza dura / srp. imati tvrdu glavu, biti tvrde glave ${ }^{12}$

fr. une tête carrée (*četvrtasta glava) / šp. tener cabeza cuadrada ${ }^{13}$ (*imati četvrtastu glavu) / srp. - .

Tvrdoglavost protkana lošom naravi u francuskom jeziku povezuje se sa svinjom: avoir une tête de cochon (*imati glavu svinje) i avoir une tête de lard (*imati glavu slanine).

Nepromišljenost, rasejanost, nehajnost, površnost, nedoslednost iskazuju naredni, prevashodno francuski frazemi i tek poneki španski frazem. U većini primera čovek sa ovakvim osobinama poredi se sa pticom:

fr. c'est une vraie tête d'oiseau (*to je prava glava ptice) / šp. - / srp. -;

fr. c'est une vraie tête de linotte (*to je prava glava konopljarke) / šp. - / srp. - ;

fr. c'est une vraie tête de moineau (*to je prava glava vrapca) / šp. - / srp. -;

fr. avoir une tête légère (*imati glavu laganu) / šp. - / srp. -;

fr. - / šp. tener la cabeza de chorlito (*imati glavu zviždovke) / srp. -;

fr. - / šp. tener, ser mala cabeza (*imati lošu glavu, biti loša glava) / srp. -.

Španska frazna imenica ${ }^{14}$ cabeza loca upućuje na lakomislenu i brzopletu osobu, te usled perifernih semantičkih različitosti nije potpuni prevodni ekvivalent srpske frazne imenice luda glava, koja može da bude konotirana, bilo pozitivno, bilo negativno, u zavisnosti od konteksta. Luda glava je tako, s jedne strane, izraz

\footnotetext{
${ }^{12}$ U svim trima posmatranim jezicima frazem ima i značenje 'čovek koji teško shvata', te je svrstan i u grupu frazema koji se odnose na umne odlike.

13 Španski frazem je polisemičan, te ga u daljem tekstu navodimo i uz deskriptore 'biti metodičan', 'biti istrajan'.

${ }^{14}$ Pod fraznom imenicom podrazumevamo posebnu vrstu bezglagolskih fraznih leksema realizovanih imeničkim sintagmama, najčešće kao kolokacije oblika pridev + imenica (Prćić, 2008: 163).
} 
naklonosti prema osobi čije nam je ponašanje simpatično, a sa druge opisuje nepouzdanu i nezrelu osobu.

U francuskom i španskom jeziku pronašle smo po jedan frazem koji upućuje na to da čovek menja ponašanje i karakter, odnosno da postaje gord i uobražen kada stekne slavu i/ili moć:

fr. avoir, prendre la grosse tête (*imati, uzeti debelu glavu) / šp. - / srp. -;

fr. - / šp. subirsele (el humo) a la cabeza (*penjati se (dim) u glavu) / srp. - .

Istu semantiku pronalazimo i u narednim frazemima, koji mogu da se prošire raznolikim komponentama, najčešće leksemama: slava, moć, vlast, popularnost, novac:

fr. la gloire, le pouvoir monte à la tête de quelqu'un (*slava, moć penje se u glavu kome) / šp. subirse a alguien la fama, el poder a la cabeza (*penje se kome slava, moć u glavu) / srp. -;

fr. - / šp. - / srp. udarila slava, moć kome u glavu.

Razdražljiv i naprasit karakter oličavaju naredni frazemi:

fr. avoir la tête chaude (*imati glavu vruću) / šp. ser cabeza caliente (*biti glave vruće) / srp. -;

fr. avoir la tête près du bonnet (*imati glavu blizu kape) / šp. - / srp. - .

Određeni broj frazema sa somatizmom glava izražava različite koncepte u trima posmatranim jezicima. Tako pojedine nepoželjne karakterne odlike uočavamo samo u francuskom jeziku:

- 'biti nepokoran, jogunast', 'biti buntovan':

fr. faire la mauvaise tête (*praviti lošu glavu) / šp. - / srp. -;

fr. faire la forte tête (*praviti jaku glavu) / šp. - / srp. -;

- 'biti bojažljiv', 'biti podložan tuđem uticaju': fr. tête faible (*glava slaba) / šp. - / srp. -;

- 'osoba koja se dobrovoljno i bez razmišljanja izlaže riziku': fr. être une tête brûlée (*biti glave izgorele) / šp. - / srp. - .

Druge su pak svojstvene samo španskom ili samo srpskom jeziku: 
- 'biti licemeran':

fr. - / šp. ser cabeza torcida (*biti glava uvrnuta) / srp. -;

- 'biti nepostojan u sudovima i idejama':

fr. - / šp. ser flaco de cabeza (*biti mršav u glavi) / srp. -;

- 'biti kukavica':

fr. - / šp. meter, esconder la cabeza debajo de ala (*staviti, sakriti glavu ispod krila) / srp. -;

- 'biti sklon spletkarenju':

fr. - / šp. - / srp. zavadio bi dva oka u glavi;

- 'biti zanesenjak', 'biti nedokazan', 'biti umišljen':

fr. - / šp. - / srp. biti usijana glava;

- 'nepouzdana, prevrtljiva osoba':

fr. - / šp. - / srp. ne moći uhvatiti koga ni za glavu ni za rep.

Pozitivne karakterne odlike znatno su manje zastupljene u našem korpusu:

- 'biti hladnokrvan':

fr. avoir la tête froide / šp. tener la cabeza fría / srp. imati hladnu glavu; ${ }^{15}$

fr. - / šp. tener la cabeza en su sitio (*imati glavu na svom mestu) / srp. -;

- 'biti metodičan', 'biti istrajan':

fr. - / šp. tener cabeza cuadrada (*imati glavu četvrtastu) / srp. - .

2.2.3. INTELEKTUALNE ODLIKE. U ovu grupu uvrstile smo frazeme koji se odnose na čovekove intelektualne odlike i aktivnosti.

U kognitivnoj lingvistici GLAVA se prvenstveno konceptualizuje kao prototipičan trodimenzionalni ČOVEKOV MENTALNI PROSTOR ${ }^{16}$ koji se razume pomoću metafore MENTALNI PROSTOR JE FIZIČKI PROSTOR, odnosno MENTALNI PROSTOR JE SADRŽATELJ koji sadrži MATERIJU KOJA ISPUNJAVA ČOVEKOV MENTALNI PROSTOR.

Podlogu frazema u ovoj grupi čini druga semantička realizacija lekseme glava ('pamet, inteligencija; misli, svest, sećanje; shvatanje, duh' (RSANU)), koja se zasniva na logičkoj metonimijskoj vezi po modelu DEO TELA $\rightarrow$ FUNKCIJA KOJU

\footnotetext{
${ }^{15}$ Frazemi mogu da ukazuju i na čovekovo stanje i ponašanje.

${ }^{16}$ O pojmovnim metaforama videti više u: Kövecses, 2000; Lakoff-Johnson, 1980.
} 
OBAVLJA ili GLAVA $\rightarrow$ ONO ŠTO JE U NJOJ (Štrbac-Štasni, 2017: 35-36), odnosno GLAVA $\rightarrow$ MOZAK. Tako se stvarne odlike i funkcije mozga (npr. pamet, um, razum, razmišljanje, zaključivanje, analiziranje) zapravo pripisuju glavi:

fr. avoir quelque chose dans la tête / šp. - / srp. imati nešto u glavi;

fr. - / šp. - / srp. imati soli u glavi;

fr. - / šp. - / srp. imati zrno, dva zrna soli u glavi;

fr. - / šp. - / srp. imati malo više u glavi;

fr. - / šp. - / srp. lako ide, ulazi u glavu;

fr. - / šp. - / srp. imati klikere u glavi;

fr. - / šp. - / srp. imati mozga u glavi.

Na izuzetnu pamet upućuju i naredni frazemi:

fr. avoir, être une bonne tête / šp. ser (hombre de) buena cabeza / srp. imati dobru glavu;

fr. être une tête d'ampoule (*biti glava sijalice) / šp. - / srp. -;

fr. avoir, être une forte tête (*imati, biti snažna glava) / šp. - / srp. -;

fr. avoir une grosse tête ${ }^{17}$ (*imati debelu glavu) / šp. - / srp. -;

fr. - / šp. ser cabeza de huevo (*biti glava jajeta) / srp. -;

fr. - / šp. tener cabeza (*imati glavu) / srp. -;

fr. - / šp. tener la cabeza bien amueblada (*imati glavu dobro tapaciranu) / srp. -;

fr. - / šp. tener cabeza para algo (*imati glavu za nešto) / srp. - .

U francuskom jeziku pronalazimo frazeme u kojima se pored pameti ističe $\mathrm{i}$ neka druga osobina, pozitivna ili negativna:

- 'biti pametan i odlučan':

fr. être une femme, un homme de tête (*biti žena, muškarac od glave) / šp. - / srp. -;

- 'biti pametan i usled toga nadmen':

fr. avoir une grosse tête (*imati debelu glavu) / šp. - / srp. - .

Na prisebnu i razumnu osobu upućuju naredni francuski i španski frazemi:

\footnotetext{
${ }^{17}$ Ima i značenje 'biti pametan i usled toga nadmen', te je svrstan još jednom u ovo polje sa drugim deskriptorom.
} 
fr. avoir la tête sur les épaules (*imati glavu na ramenima) / šp. tener la cabeza sobre los hombros (*imati glavu na ramenima) / srp. -;

fr. garder la tête sur les épaules ${ }^{18}$ (*čuvati glavu na ramenima) / šp. - / srp. -;

fr. avoir toute sa tête ${ }^{19}$ (*imati celu svoju glavu) / šp. - / srp. -;

fr. - / šp. tener la cabeza bien puesta sobre sus hombros (*imati glavu dobro postavljenu na svojim ramenima) / srp. -;

fr. - / šp. estar bien de la cabeza (*biti dobro u glavi) / srp. - .

U ovu grupu svrstale smo i frazeološke jedinice suprotne semantičke sadržine kojih je znatno više. Njihova brojnost ne iznenađuje, budući da je čoveku svojstveno da uočava svako udaljavanje od proseka, čime se potvrđuje jedan od osnovnih principa frazeoloških univerzalija, po kojem se upravo negativne karakteristike, stanja ili vrednovanja češće izražavaju frazemima.

Oskudne intelektualne sposobnosti i neznanje odslikavaju naredni, prevashodno španski frazemi. U većini su uočljive pojmovne metafore GLAVA JE PRAZAN SADRŽATELJ i GLAVA JE SADRŽATELJ BEZNAČAJNIH PREDMETA (npr. so, voda, ptice, slama):

fr. avoir la tête creuse / šp. tener cabeza hueca / srp. imati šuplju glavu;

fr. avoir une tête sans-cervelle / šp. - / srp. nemati mozga u glavi;

fr. avoir la tête faible (*imati glavu slabu) / šp. - / srp. -;

fr. avoir une petite tête (*imati malu glavu) / šp. - / srp. -;

fr. - / šp. tener cabeza de tarro (*imati glavu ćupa) / srp. -;

fr. - / šp. tener alguien poca cabeza (*imati neko malo glave) / srp. -;

fr. - / šp. tener cabeza redonda (*imati glavu okruglu) / srp. -;

fr. - / šp. ser cabeza de alcornoque (*biti glava hrasta) / srp. -;

fr. - / šp. tener agua en la cabeza (*imati vodu u glavi) / srp. -;

fr. - / šp. tener la cabeza llena de serrín (*imati glavu punu piljevine) / srp. -;

fr. - / šp. - / srp. imati slamu u glavi.

Izvestan broj frazema ukazuje na osobu koja nije pri zdravoj pameti i koja se ponaša nerazumno i luckasto:

\footnotetext{
${ }^{18}$ Srpski frazem sačuvati glavu na ramenima ima različit semantički sadržaj.

${ }^{19}$ Frazem se odnosi prevashodno na stare i bolesne ljude koji su uspeli da sačuvaju zdrav razum i lucidnost.
} 
fr. être tombé sur la tête / šp. - / srp. pasti na glavu;

fr. ne pas avoir toute sa tête (*nemati svu svoju glavu) / šp. - / srp. -;

fr. - / šp. írsele a alguien la cabeza (*otići kome glava) / srp. -;

fr. - / šp. descomponersele a alguien la cabeza (*raspadati se kome glava) / srp. -;

fr. - / šp. estar podrido de cabeza (*biti truo u glavi) / srp. -;

fr. - / šp. estar mal de la cabeza (*biti loše u glavi) / srp. -;

fr. - / šp. estar tocado de cabeza (*biti taknut po glavi) / srp. -;

fr. - / šp. tener pájaros en la cabeza (*imati ptice u glavi) / srp. -;

fr. - / šp. - / srp. biti udaren mokrom čarapom po glavi;

fr. - / šp. - / srp. biti udaren mokrom krpom po glavi;

fr. - / šp. - / srp. đavo je ušao kome u glavu.

GLAVA se poima i kao GRAĐEVINA kojoj nedostaje deo materijala (daska) i kroz koju može da duva promaja:

fr. - / šp. - / srp. duva kome promaja kroz glavu;

fr. - / šp. - / srp. nemati sve daske u glavi.

U frazemu faliti, nedostajati kome daska u glavi stepen čovekovog udaljavanja od razumnog stanja može da se izrazi i brojem - faliti kome jedna/treća (i slično) daska u glavi. Mršević-Radović (1987: 127), međutim, smatra da brojevi u ovom frazemu nemaju stvarnu vrednost, te da oni u primarnom frazemu zapravo imaju značenje neki.

Brojni frazemi iz ove skupine odnose se na raznolike umne aktivnosti razmišljanje, shvatanje, sećanje, zaboravljanje.

$\mathrm{U}$ francuskom frazemu se creuser la tête (*sebi kopati glavu) opšte značenje 'misliti o nečemu' protkano je dodatnom semantičkom nijansom 'naprezati se razmišljajući'.

Intenzivno razmišljanje o nečemu teškom i složenom, propraćeno napetošću, naporom i težnjom za razrešenjem nepoznanice imenuju sledeći negativno konotirani frazemi $\mathrm{u}$ kojima glagolske komponente impliciraju destrukciju (videti: Mušović, 2002):

fr. se casser la tête / šp. romperse, partirse, quebrarse la cabeza / srp. razbijati, lupati glavu; 
fr. - / šp. - / srp. puca kome glava (od razmišljanja $)^{20}$.

Ovakav mentalni napor metaforično može da dovede i do ,zagrevanja” misli i emocija koje ispunjavaju čovekovu glavu:

fr. - / šp. calentarse la cabeza (*zagrejati se glava) / srp. -;

fr. - / šp. - / srp. usijala se glava kome;

fr. - / šp. - / srp. puši se kome glava (od razmišljanja).

Koncept razmišljanja leksikalizuje se u srpskom jeziku i putem frazema mućnuti, mućkati glavom u kojem se glava poima kao zatvorena posuda sa tečnošću koju je neophodno (pro)mućkati kako bi se podstaklo „nataloženo” znanje.

Naredni frazemi ukazuju na to da čovek može da bude samostalan u razmišljanju ili da se povede za tuđim mišljenjem:

fr. penser avec sa propre tête / šp. pensar con cabeza propia / srp. misliti svojom glavom;

fr. penser avec la tête d'autrui / šp. pensar con cabeza ajena / srp. misliti tuđom glavom;

fr. - / šp. andar por su cabeza (*ići za svojom glavom) / srp. - .

U frazemima u kojima se iskazuje kakva iznenadna (po)misao, odnosno ideja, glagol kretanja obavezna je komponenta, budući da se u pozadinskoj slici pojavljuje pojmovna metafora MISLI/IDEJE SU PUTUJUĆI ENTITETI:

fr. venir à, dans la tête, en tête / šp. venir a la cabeza / srp. doći u glavu;

fr. passer par la tête / šp. pasarse por la cabeza / srp. proći, prolaziti kroz glavu;

fr. - / šp. - / srp. proleteti kroz glavu.

Istovetan sadržaj nose, $\mathrm{s}$ jedne strane, španski frazem levantar de su cabeza (*podići iz svoje glave) i, sa druge, srpski frazem sinuti u glavi, čija glagolska komponenta pripada domenu svetlosti koja se vezuje za pozitivne koncepte.

\footnotetext{
${ }^{20}$ Druga značenja ovog polisemičnog frazema ('biti zabrinut' i 'imati jaku glavobolju') nisu predmet ovog rada.
} 
Slično značenje sa primesom hirovitosti realizuje se i u srpskom frazemu dunuti u glavu koji pripada razgovornom jeziku. Semantički sadržaj upućuje na kakve nerazumne misli ili ponašanje. Frazem je utemeljen na relevantnim fizičkim karakteristikama vetra kao stihije ili prirodne sile (Mršević-Radović, 1987: 88-91). Iako se vetar u frazemu ne navodi eksplicitno, on je semantički povezan sa glagolom duvatildu(h)nuti. Otuda i semantika frazema koja počiva na simbolici vetra - ispraznost, nepostojanost, nestalnost (RSJ).

Prisustvo neočekivanih i hirovitih (za)misli, koje mogu da dovedu do nerazumnih postupaka, izražava srpski frazem imati bube u glavi.

Pojmovna metafora MISLI/IDEJE SU PUTUJUĆI ENTITETI prisutna je i u pozadinskoj slici frazema koji ukazuju na neprestano prisustvo misli:

fr. ne pas sortir de la tête de quelqu'un / šp. no salirsele a alguien de la cabeza / srp. ne izlaziti kome iz glave;

fr. tourner quelque chose dans la tête / šp. rondarle algo, alguien por la cabeza / srp. vrteti nešto po glavi, vrteti se po glavi;

fr. - / šp. meterse en la cabeza (*staviti sebi u glavu) / srp. -;

fr. - / šp. - / srp. vrzmati se, motati se po glavi.

Naredni frazemi ukazuju na (ne)sposobnost učenja i shvatanja:

fr. (ne pas) (r)entrer dans la tête / šp. (no) entrar en la cabeza / srp. (ne) ući, ulaziti u glavu;

fr. avoir la tête dure / šp. tener la cabeza dura / srp. imati tvrdu glavu;

fr. - / šp. - / srp. ne ići u glavu;

fr. - / šp. - / srp. teško ići u glavu.

Kognitivna radnja pamćenja i (pri)sećanja prisutna je u sledećim frazemima:

fr. avoir en tête, dans la tête / šp. - / srp. imati u glavi;

fr. - / šp. - / srp. držati u glavi.

U nekoliko srpskih frazema osnovno značenje 'misliti o nečemu' stapa se sa značenjem '(pri)sećati se':

fr. - / šp. - / srp. kopati po glavi; 
fr. - / šp. - / srp. prebirati, preturati, premetati po, u glavi;

fr. - / šp. - / srp. tražiti po glavi.

Ideju zaboravljanja izražavaju naredni frazemi u kojima se misli, događaji, emocije i osobe konceptualizuju kao predmeti ili tečnost koja može da ispari i tako nestane. Kod većine postoji želja i/ili namera da se neko ili nešto zaboravi:

fr. effacer, supprimer de la tête / šp. borrar de la cabeza / srp. izbrisati iz glave;

fr. chasser de la tête / šp. quitar de la cabeza / srp. izbaciti iz glave;

fr. s'enlever de la tête / šp. sacarse de la cabeza / srp. izbiti iz glave;

fr. se sortir quelque chose, quelqu'un de la tête / šp. - / srp. -;

fr. - / šp. - / srp. ispariti, izvetriti iz glave.

2.2.4. MoRALNE ODLIKE. Poslednja grupa frazema sa somatizmom glava odnosi se na moralne osobine. U njoj se nalaze svega dve jedinice, jedna francuska i jedna srpska, koje upućuju na odsustvo moralnosti:

fr. avoir du beurre sur la tête / šp. - / srp. imati putera na glavi.

\section{ZAKLJUČAK}

U radu smo uporedile francuske, španske i srpske frazeme sa somatizmom fr. tête / šp. cabeza / srp. glava koji izražavaju čovekove fizičke, karakterne, umne i moralne osobine. S obzirom na to da smo obuhvatile samo jedno konceptualno polje ('čovekove osobine'), možemo da zaključimo da su ovi frazemi brojni (174), kao i da $\mathrm{u}$ ovom segmentu posmatrani somatizam ima sličnu frazemotvornu aktivnost $u$ trima lingvokulturološkim zajednicama (od ukupnog broja frazema u korpusu, 63 su francuska, 52 španska i 59 srpskih).

Metodom leksičko-semantičke kontrastivne analize ustanovile smo podudaranje frazema u 15 slučajeva u trima jezicima (ukupno 45 frazema), odnosno u 13 slučajeva u dvama jezicima (francuski/španski - 6, španski/srpski - 1 , francuski/srpski - 6). Zanimljivo je istaći da se, uprkos brojčanoj ujednačenosti frazema u našoj građi i njihovoj utemeljenosti na metaforičkim i metonimijskim preslikavanjima, $\mathrm{u}$ francuskom, španskom i srpskom jeziku glava ne poima istovetno, budući da smo u korpusu uočile veliki broj bezekvivalentnih frazema (36 francuskih, 30 španskih i 37 srpskih). 
Ovo je veoma neuobičajeno s obzirom na to da su somatski frazemi uglavnom nastali preslikavanjem osobina čovekovog tela, kao i na osnovu konvencionalnog znanja (o obliku, funkciji, položaju i pokretima glave) koje je univerzalno i ne poznaje rasne i nacionalne razlike. Pojedine bezekvivalentne primere u našem korpusu možemo da objasnimo činjenicom da neke koncepte (npr. pamet, nerazumnost, glupost) iskazuje više frazema istovetne semantike, koji se u trima jezicima različito leksički formalizuju.

Brojni su frazemi zasnovani na univerzalnoj pojmovnoj metafori MENTALNI PROSTOR JE FIZIČKI PROSTOR, OdnOSnO MENTALNI PROSTOR JE SADRŽATELJ koji sadrži MATERIJU KOJA ISPUNJAVA ČOVEKOV MENTALNI PROSTOR, iz koje izvire logička metonimijska veza po modelu DEO TELA $\rightarrow$ FUNKCIJA KOJU OBAVLJA ili GLAVA $\rightarrow$ ONO ŠTO JE U NJOJ, odnosno GLAVA $\rightarrow$ MOZAK, kao i podmetafore GLAVA JE PRAZAN SADRŽATELJ i GLAVA JE SADRŽATELJ BEZNAČAJNIH PREDMETA. Neznatan broj leksičko-semantičkih poklapanja u trima jezicima utemeljen je na univerzalnoj metafori MISLI/IDEJE SU PUTUJUĆI ENTITETI.

Najbrojniji su frazemi koji kvalifikuju čovekove karakterne i umne osobine, kao i aktivnosti. Podgrupe kojima se iskazuju čovekov fizički izgled i moralne osobine oskudnije su po broju frazeoloških jedinica. Posmatrani frazemi u svim trima jezicima otkrivaju prvenstveno nepoželjne osobine čovekovog karaktera (tvrdoglavost, nepromišljenost, rasejanost, površnost, gordost, razdražljivost), kao i manjkavost intelektualnih sposobnosti i neznanje. Osim toga, brojnim frazemima omalovažava se čovekov fizički izgled, budući da se njihova izuzetna ekspresivnost postiže poređenjem sa kakvom životinjom, predmetom ili voćem okruglog ili duguljastog oblika.

Pojedine nepoželjne osobine zabeležene su samo u francuskom (nepokornost, bojažljivost, povodljivost, nepromišljeno izlaganje riziku), odnosno španskom (licemerje, nepostojanost u sudovima i idejama, kukavičluk) ili srpskom delu korpusa (spletkarenje, nedokazanost, prevrtljivost). Poželjne osobine (prisebnost, (raz)umnost, istrajnost, hladnokrvnost) prisutne su u neznatnom broju slučajeva. Osim toga, metonimijski odnos CELINA ZA DEO pronalazimo samo u francuskom jeziku.

Kod većine posmatranih frazema pozadinska slika je lako uočljiva, razumljiva i predvidljiva, budući da sve komponente frazema zadržavaju primarno značenje (npr. fr. avoir la tête [grosse] comme une citrouille; avoir la tête [grosse] comme une pastèque; šp. tener cabeza de tarro; tener cabeza como caballo; srp. imati glavu [veliku] kao bundeva; imati glavu kao svinjalbik/tele), ili je u njima desemantizacija delimična (npr. fr. avoir une tête pelée; šp. tener la cabeza pelada; srp. imati soli u glavi). Kod pojedinih frazema značenje nije transparentno, usled 
potpune desemantizacije komponenata frazema (npr. fr. une tête carrée; avoir la tête près du bonnet; šp. tener cabeza cuadrada; subirsele (el humo) a la cabeza; srp. biti udaren mokrom čarapom po glavi).

\author{
Ksenija Šulović, Dragana Drobnjak, Snežana Gudurić
}

\title{
PHRASEMS WITH SOMATISM HEAD IN FRENCH, SPANISH AND SERBIAN
}

Conceptual field 'human characteristics'

\section{Summary}

This paper deals with French, Spanish and Serbian phrasemes with the lexeme Fr. tête / Sp. cabeza / Ser. glava that qualify human personality and intelligence and one`s physical and moral traits. By using the method of contrastive semantic analysis, the aim of this study was to determine the extent of the lexical and semantic structure of the extracted 174 examples as well as the (non) matching of the concepts they express. A lexical and semantic matching in three languages was found in 15 cases (45 phrasemes), while the same matching in two languages was noted in only 13 cases ( 26 phrasemes). In the three languages, the head is not conceptualized in the same manner, which is demonstrated by zero equivalence in a large number of examples (104). Such an imageis unusual since somatismes are largely based on the mapping of properties of the human body, which is universal. The large number of nonequivalent phrases is due to the fact that several phrasemes of identical semantics but different lexical realizations describe different individual traits (e.g. wit, lack of reason, stupidity).

The most numerous are phrasemes that qualify human character and its intellectual properties and activities, while those which express human physical appearance and moral characteristics occur in a far smaller number. In the three languages, the phrases observed reveal primarily negative traits of a person's character (stubbornness, recklessness, being scatterbrained, superficiality, irritability), as well as poor intellectual ability. Numerous phrasemes carry a negative connotation towards one`s physical appearance, and compare it to the appearance of an animal, the shape of an object or a piece of fruit. Some of the undesirable features were noted only in French (rebelliousness, fearfulness, impudence, ruthless exposure to risk), only in Spanish (lack of courtesy or ideas, cowardice) or only in Serbian (scheming, hypocrisy). Desirable properties (attachment, rationality, persistence, cold bloodedness) are present in a small number of cases.

In all the phrasemes analyzed, the background image is easily visible, understandable and predictable.

Key words: head, phraseology, conceptual field 'human characteristics', French, Spanish, Serbian 


\section{LITERATURA}

Andrić, E. (2013). Kontrastivna semantička analiza reči fej u mađarskom i glava u srpskom jeziku. Zbornik Matice srpske za filologiju i lingvistiku, knj. 56, sv. 2: 131-153.

Burger, H. (2003). Phraseologie. Eine Einführung am Beispiel des Deutschen. Berlin: Erich Schmidt Verlag.

Cortès, C. (1998-1999). Phraséologie et corps humain. Etude comparative de la représentation du corps humain dans les expressions phraséologiques en français et en allemand. Cahier du C.I.E.L., 6: 85-109.

Ĉermák, F. (2000). Revisando los idiomatismos somáticos. U: Durán J.D. Luque, A. Pamies Bertrán. (ur.) (2000), Trabajos de lexicografía y fraseología contrastivas. Granada: Método. 55-62.

Dragićević, R. (2009). O problemima identifikacije frazeologizama. Südslavistik online, 1: 35-44.

Drobnjak, D., Šulović, K. (2016). Lingvokulturološki triptih. Novi Sad: Filozofski fakultet.

Kovačević, B. (2012). Hrvatski frazemi od glave do pete. Zagreb: Institut za hrvatski jezik i jezikoslovlje.

Kövecses, Z. (2000). Metaphor and Emotion: Language, Culture, and Body in Human Feeling. Cambridge: Cambridge University Press.

Kövecses, Z. (2002). Metaphor. A Practical Introduction. New York: Oxford University Press.

Lakoff, G., Johnson, M. (1980). Metaphors We Live by. Chicago: University of Chicago Press.

Lakoff, G., Turner, M. (1989). More Than Cool Reason. A Field Guide to Poetic Metaphor. Chicago: The University of Chicago Press.

Marjanović, P. S. (2017). Značenjske odlike poredbenih frazema francuskoga i srpskog jezika. Jezici i kulture u vremenu i prostoru VI, tematski zbornik (ur. S. Gudurić, B. Radić-Bojanić), Novi Sad: Univerzitet u Novom Sadu, Filozofski fakultet. 147-162. (štampano ćirilicom)

Mršević-Radović, D. (1987). Frazeološke glagolsko-imeničke sintagme u savremenom srpskohrvatskom jeziku. Beograd: Filološki fakultet. (štampano ćirilicom)

Mušović, A. (2002). Somatske frazeološke jedinice za izražavanje emocija i njihova sintaksička funkcija. Kosovska Mitrovica: Filozofski fakultet.

Olza Moreno, I. (2006). Las partes del cuerpo humano como bases metonímicas en la fraseología metalingüística del español, Actes del VII Congrés de 
Lingüística General, Barcelona: Publicacions i Edicions de la Universitat de Barcelona, 1-18.

Prćić, T. (2008). Semantika i pragmatika reči. Novi Sad: Zmaj.

Razdobudko-Čović, L. (2003). Semantika i pragmatika somatizama u srpskom $i$ ruskom jeziku. Beograd: Vedes. (štampano ćirilicom)

Ristić, G. (2013). Somatizmi u nemačkoj i srpskoj frazeologiji (kontrastivna istraživanja). Univerzitet u Novom Sadu, Filozofski fakultet. (doktorska disertacija)

Trivić, A. (2015). Leksičko-semantička analiza somatizama u frazeologiji savremenog španskog $i$ srpskog jezika: kontrastivni pristup. Univerzitet u Kragujevcu, FILUM. (doktorska disertacija: http://eteze.kg.ac.rs/ application/showtheses?thesesId=1788)

Štrbac, G., Štasni, G. (2017). Somatizmi i konceptualizacija stvarnosti u srpskom jeziku. Novi Sad: Filozofski fakultet. (štampano ćirilicom)

Zybatow, L. (1997). Idiome und Parömien aus kognitivlinguistischer und translationslinguistischer Sicht (am Beispiel des Russischen und Ukrainischen). U: Internationale Tendenzen der Syntaktik, Semantik und Pragmatik. Akten des 32. Linguistischen Kolloquiums in Kassel 1997 (Hrsg. O. Spillmann / I. Warnke), Peter Lang - Europäischer Verlag der Wissenschaften: $579-588$.

\section{IZVORI}

Ashraf, M., Miannay, D. (1995). Dictionnaire des expressions idiomatiques françaises. Paris: Librairie générale de France.

Buitrago, A. (2000). Diccionario de dichos y frases hechas. Madrid: Editorial Espasa Calpe, S.A.

Clave Diccionario de uso del español actual (2002). Madrid: Ediciones SM.

DRAE: Diccionario de la lengua española (1992). Madrid: Real Academia Española.

Drašković, V. (1990). Francusko-srpskohrvatski frazeološki rečnik. Beograd: Zavod za udžbenike i nastavna sredstva.

Larousse, Dictionnaire encyclopédique illustré. (1993). Paris: Larousse.

Le nouveau Petit Robert, Dictionnaire alphabétique et analogique de la langue française. (2005). Paris: Robert.

Matijašević, J. (2003). Semantičko-derivacioni rečnik. Sv. 1: Čovek - delovi tela (red. D. Gortan-Premk, V. Vasić, Lj. Nedeljkov). Novi Sad: Filozofski fakultet, Odsek za srpski jezik i lingvistiku. (štampano ćirilicom) 
Milosavljević, B. (1994). Srpsko-francuski rečnik idioma i izreka. Beograd: Srpska književna zadruga. (štampano ćirilicom)

Otašević, Đ. (2012). Frazeološki rečnik srpskog jezika. Novi Sad: Prometej. (štampano ćirilicom)

Rey, A. (2000). Le Robert, Dictionnaire historique de la langue française. Paris: Dictionnaires Le Robert.

RSANU: Rečnik srpskohrvatskog književnog $i$ narodnog jezika. (1959-2007). Beograd: SANU. (štampano ćirilicom)

RSJ: Rečnik srpskoga jezika. (2007). Novi Sad: Matica srpska. (štampano ćirilicom) Seco, M., Andrés, O., Ramos, G. (2009). Diccionario fraseológico documentado del español actual: locuciones y modismos españoles. Madrid: Aguilar.

TLF: Trésor de la langue française: dictionnaire de la langue du XIX et du XX siècle (1971-1994). Paris: Éd. du CNRS - Klincksieck: Gallimard. 